\title{
STUDI ESTIMASI CURAH HUJAN PADA KONDISI CUACA EKSTREM TAHUN 2017 MELALUI CITRA MODIS LEVEL 1B DI PROVINSI JAWA TIMUR
}

\author{
Teguh Hariyanto ${ }^{1}$, Cherie Bhekti Pribadi ${ }^{2}$, Fendra Dwi Ramadhan ${ }^{3}$ \\ 1,2,3 Departemen Teknik Geomatika, FTSLK-ITS, Kampus ITS Sukolilo, Surabaya, 60111, Indonesia \\ e-mail:fendra.dwi14@mhs.geodesy.its.ac.id ${ }^{1}$,teguh_hr@geodesy.its.ac.id², cheriepribadi@gmail.com³
}

\begin{abstract}
Abstrak
Cuaca ekstrem merupakan keadaan atau fenomena fisik atmosfer pada waktu tertentu, berskala jangka pendek dan bersifat ekstrem. Citra satelit MODIS merupakan salah satu citra penginderaan jauh yang dapat digunakan untuk pemantauan curah hujan khususnya di wilayah tropis seperti Indonesia. Dalam kajian meteorologi, citra satelit MODIS dapat menyadap berbagai informasi terkait parameter pendukung curah hujan seperti halnya suhu permukaan awan (SPA) dan albedo awan (ALB). Cara estimasi menggunakan metode regresi linier berganda dengan parameter curah hujan aktual, suhu permukaan awan (SPA) dan albedo awan (ALB), nilai intensitas curah hujan yang diperol eh dari citra MODIS berupa estimasi minimal pada bulan Oktober hingga Desember sebesar $0 \mathrm{~mm} /$ hari dan estimasi maksimal pada bulan Oktober sebesar 14,977 mm/hari, bulan November sebesar 18,515 mm/hari dan bulan Desember sebesar 15,332 $\mathrm{mm} /$ hari. Pada hasil analisis spasial menunjukkan bahwa ketiga kelas curah hujan ( $<5 \mathrm{~mm} / \mathrm{hari,} 5-20 \mathrm{~mm} / \mathrm{hari}$ dan 20 - $50 \mathrm{~mm} /$ hari) tersebar di ketiga kelas ketinggian wilayah (Dataran Rendah, Dataran Sedang dan Dataran Tinggi) di Provinsi Jawa Timur, dengan luas luas wilayah curah hujan estimasi pada bulan Oktober terbanyak pada tanggal 27 Oktober 2017 sebesar 39.888 km², pada bulan November terbanyak pada tanggal 28 November 2017 sebesar 47.584 $\mathrm{km}^{2}$, sedangkan pada bulan Desember terbanyak pada tanggal 26 Desember 2017 sebesar 45.903 km².
\end{abstract}

Kata kunci : Albedo Awan, Curah Hujan, MODIS, Regresi Linier Berganda, Suhu Permukaan Awan

\section{PENDAHULUAN}

Letak geografis Indonesia yang berada di region lintang rendah (low latitudes) dengan kondisi wilayah perairan sebesar $70 \%$ menyebabkan jumlah air yang menguap sangatlah besar sehingga formasi awan hujan yang terbentuk bervariasi dan juga menimbulkan fluktuasi cuaca. Salah satu indikator fluktuasi cuaca adalah adanya kondisi cuaca ekstrem pada beberapa wilayah di Indonesia (Tjasyono 2009). Pada tahun 2017, BMKG Juanda mengeluarkan peringatan cuaca ektrem yang berlaku mulai tanggal $26-28$ November 2017 di wilayah Provinsi Jawa Timur yang telah menyebabkan adanya potensi hujan lebat hingga ekstrem di wilayah tersebut. Cuaca ekstrem merupakan keadaan atau fenomena fisik atmosfer pada waktu tertentu, berskala jangka pendek dan bersifat ekstrem. BMKG mengkategorikan salah satu kriteria cuaca ekstrem terjadi apabila curah hujan bernilai $\geq 20$ $\mathrm{mm} /$ jam atau $\geq 100 \mathrm{~mm} /$ hari (BMKG 2017).

Pemantauan curah hujan dapat diketahui melalui pemanfaatan alat-alat pemantau cuaca secara konvensional, namun dengan semakin berkembangnya teknologi penginderaan jauh, pemantauan curah hujan pun dapat dilakukan dengan menggunakan data citra satelit penginderaan jauh. Citra satelit MODIS (Moderate Resolution Imaging Spectroradiometer) merupakan salah satu citra penginderaan jauh yang dapat digunakan untuk pemantauan curah hujan khususnya di wilayah tropis seperti Indonesia. Dalam kajian meteorologi, citra satelit MODIS dapat menyadap berbagai informasi terkait parameter pendukung curah hujan seperti halnya suhu permukaan awan dan al bedo awan (Darajat 2014). Penelitian ini secara khusus membahas dan menganalisis tentang pola estimasi curah hujan pada kondisi cuaca ekstrem bulan Oktober hingga Desember 2017 melalui citra satelit MODIS Level 1B di Provinsi Jawa Timur. Estimasi curah hujan dilakukan dengan menggunakan metode regresi linier berganda dengan parameter curah hujan aktual, suhu permukaan awan (SPA) dan albedo awan (ALB). Analisa spasial dilakukan untuk mengetahui pola curah hujan terhadap kondisi ketinggian wilayah di Provinsi Jawa Timur. Hasil nilai curah hujan yang didapatkan dibandingkan dengan data curah hujan hasil pengukuran secara aktual 
dari pos hujan yang tersebar di Provinsi Jawa Timur. Hasil akhir dari penelitian ini berupa peta pola curah hujan pada kondisi cuaca ekstrem bulan Oktober hingga Desember 2017 di Provinsi Jawa Timur, informasi nilai akurasi dan korelasi curah hujan hasil estimasi terhadap data aktual dan informasi hasil analisis spasial. Adapun tujuan kegiatan ini adalah menghitung nilai curah hujan dari citra satelit MODIS pada kondisi cuaca ekstrem bulan Oktober hingga Desember 2017 di Provinsi Jawa Timur;menentukan pola curah hujan serta membuat peta pola curah hujan dari citra satelit MODIS pada kondisi cuaca ekstrem bulan Oktober hingga Desember 2017 di Provinsi Jawa Timur; menghitung akurasi dan korelasi antara nilai curah hujan dari citra satelit MODIS terhadap data aktual pada kondisi cuaca ekstrem bulan Oktober hingga Desember 2017 di Provinsi Jawa Timur dan melakukan analisis spasial pola curah hujan estimasi terhadap kondisi ketinggian wilayah di Provinsi Jawa Timur

\section{METODOLOGI PENELITIAN}

Lokasi penelitian ini dilakukan di Provinsi Jawa Timur yang terletak pada $7,12^{\circ}-8,48^{\circ} \mathrm{LS} ; 111,0^{\circ}$ - 114,4 $4^{\circ}$ BT. Luas wilayah Provinsi Jawa Timur mencapai $47.799,75 \mathrm{~km}^{2}$ terbagi menjadi 38 Kabupaten atau Kota (29 Kabupaten dan 9 Kota). Provinsi Jawa Timur berbatasan dengan Laut Jawa di utara, Selat Bali di timur, Samudra Hindia di selatan, serta Provinsi Jawa Tengah di barat.

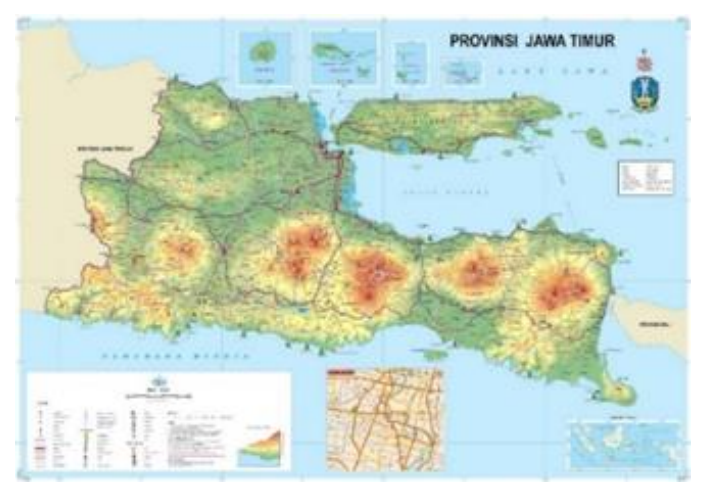

Gambar 1 Lokasi Penelitian Provinsi Jawa Timur (Bakosurtanal 2003)

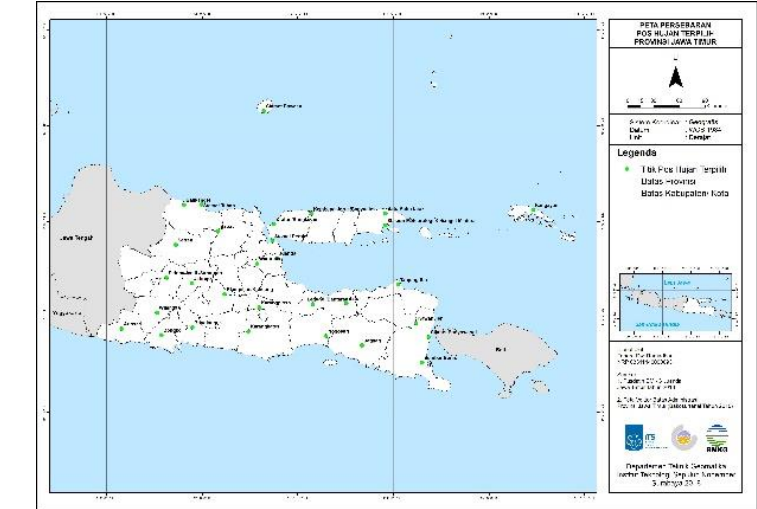

Gambar 2 Lokasi Penelitian dan Sebaran Titik Pos Hujan Terpilih (BMKG 2018)

\section{Pengolahan Data}

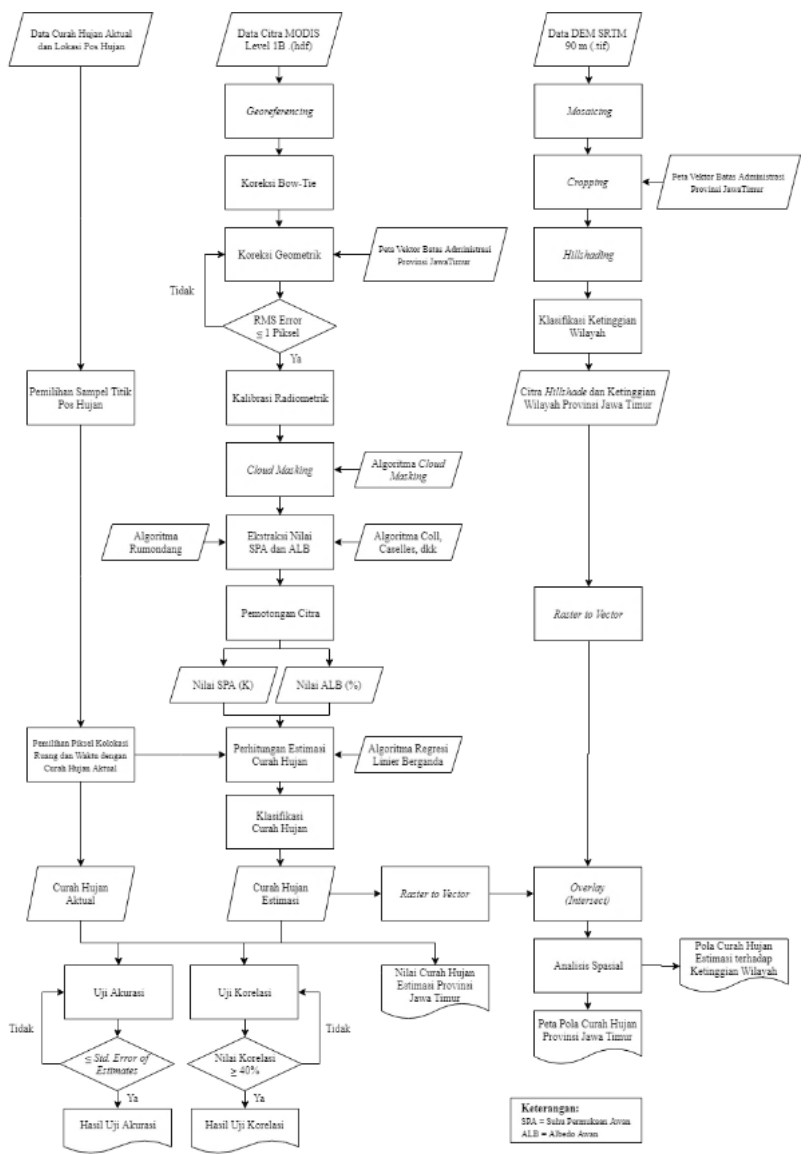

Gambar 3 Diagram Alir Pengolahan Data

\section{HASIL DAN PEMBAHASAN}

\section{Hasil Ekstraksi Nilai SPA dan ALB}

Informasi mengenai SPA dan ALB tersebut didapatkan dari citra MODIS pada kanal emissive radiance (band 31 dan band 32) dan kanal reflectance (band 1, band 3 dan band 4) melalui beberapa algoritma. MenurutBehrangi, Koulin, dkk. 
(2010), batas klasifikasi nilai SPA yang dihasilkan yaitu: (1) kurang dari 220,1 Kelvin; (2) 220,1 hingga 235 Kelvin; (3) 235,1 hingga 253 Kelvin; dan (4) lebih dari 253 Kelvin. Asumsi terhadap klasifikasi SPA tersebut, bahwa nilai SPA lebih dari 253 Kelvin (kelas ke-4) tidakmemiliki potensi hujan, sehingga tidak diberikan warna sedangkan kelas lainnya diasumsikan memiliki potensi hujan. Sedangkan, batas klasifikasi nilai ALB yang dihasilkan yaitu: (1) kurang dari 40 persen; (2) 40 hingga 54,9 persen; (3) 55 hingga 64,9 persen; dan (4) lebih dari 64,9 persen. Asumsi terhadap klasifikasi ALB tersebut, bahwa nilai ALB sebesar 40 persen hingga lebih dari 64,9 persen memiliki potensi hujan. Sedangkan, nilai ALB kurang dari 40 persen (kelas ke-1) diasumsikan tidak memiliki potensi hujan, sehingga tidak diberikan warna.

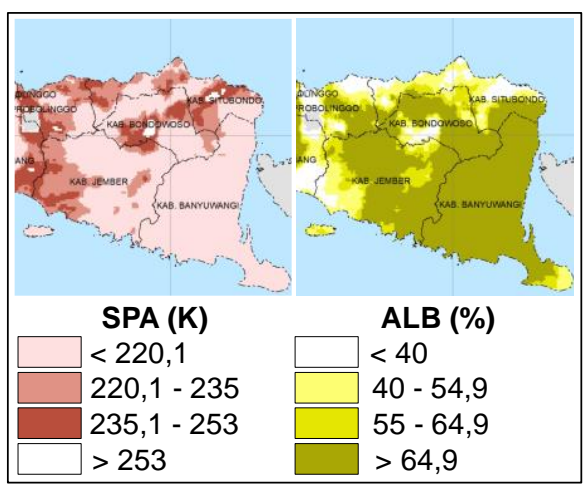

Gambar 5 Klasifikasi SPA dan ALB menurut Behrangi, Koulin, dkk (2010)

Nilai sebaran SPA dan ALB yang diekstrak dari tiaptiap titik pos hujan di Provinsi Jawa Timur bervariasi di setiap tanggal perekaman citra. Pada beberapa titik pos hujan didapat nilai N/A yang berarti pada titik tersebut tidak terdapat piksel yang memiliki nilai SPA dan ALB. Ada tidaknya piksel pada suatu citra tersebut terjadi karena beberapa hal diantaranya karena hasil proses pemotongan citra sesuai dengan wilayah kajian, tidak tertutupnya wilayah kajian oleh awan dan scene citra MODIS yang tidak sepenuhnya menutupi wilayah kajian.

\section{Hasil Persamaan Regresi Linier Berganda dalam Menentukan Curah Hujan Estimasi}

Berdasarkan hasil uji persamaan regresi linier berganda didapatkan nilai $R$ adalah 0,624 dan $R^{2}$ sebesar 0,390. Hal tersebut mengartikan bahwa terjadi hubungan yang cukup kuat antara SPA $\left(x_{1}\right)$ dan ALB $\left(x_{2}\right)$ terhadap curah hujan $(y)$. Sedangkan presentase sumbangan pengaruh SPA dan ALB terhadap nilai curah hujan, ditunjukkan oleh nilai $R^{2}$ hanya sebesar $39 \%$. Sisa dari nilai $\mathrm{R}^{2}$ sebesar $61 \%$ dipengaruhi oleh variabel lain yang tidak dimasukkan dalam penelitian ini. Nilai std. error of estimate pada hasil regresi adalah 8,730. Artinya, bahwa banyaknya kesalahan dalam estimasi nilai curah hujan sebesar 8,730 milimeter (satuan nilai curah hujan). Nilai tersebut termasuk cukup baik digunakan untuk memprediksi nilai $y$ atau curah hujan. Hal tersebut dibuktikan melalui nilai std. error of estimate yang besarannya kurang dari nilai standar deviasi nilai curah hujan, yaitu 10,853 milimeter.

Pola Intensitas Curah Hujan Estimasi pada 26, 27 dan 28 Oktober 2017

Pada tanggal 26 Oktober 2017, intensitas curah hujan estimasi di Provinsi Jawa Timur mengalami curah hujan terendah terletak di 18 pos hujan dengan intensitas curah hujan sebesar $0 \mathrm{~mm} /$ hari, sedangkan curah hujan tertinggi terletak pada Pos Hujan Juanda dengan intensitas curah hujan sebesar 14,977 mm/hari. Pada tanggal 27 Oktober 2017, intensitas curah hujan estimasi di Provinsi Jawa Timur mengalami curah hujan terendah terletak di 19 pos hujan dengan intensitas curah hujan sebesar $0 \mathrm{~mm} /$ hari, sedangkan curah hujantertinggi terletak pada Pos Hujan Kembang Jeruk/Banyuates dengan intensitas curah hujan sebesar 11,496 mm/hari. Pada tanggal 28 Oktober 2017, intensitas curah hujan estimasi di Provinsi Jawa Timur mengalami curah hujan terendah terletak di 29 pos hujan dengan intensitas curah hujan sebesar $0 \mathrm{~mm} /$ hari, sedangkan curah hujan tertinggi terletak pada Pos Hujan Klampisan/Kencong dengan intensitas curah hujan sebesar 4,098 $\mathrm{mm} /$ hari.

\section{Pola Intensitas Curah Hujan Estimasi pada 26, 27} dan 28 November 2017

Pada tanggal 26 November 2017, intensitas curah hujan estimasi di Provinsi Jawa Timur mengalami curah hujan terendah terletak di 10 pos hujan dengan intensitas curah hujan sebesar $0 \mathrm{~mm} /$ hari, sedangkan curah hujan tertinggi terletak pada Pos Hujan Babat dengan intensitas curah hujan sebesar 15,604 mm/hari. Pada tanggal 27 November 2017, intensitas curah hujan estimasi di Provinsi Jawa Timur mengalami curah hujan terendah terletak pada Pos Hujan Stasiun Meteorologi Kalianget Madura dengan intensitas curah hujan sebesar 0 $\mathrm{mm} /$ hari, sedangkan curah hujan tertinggi terletak pada Pos Hujan Karangploso dengan intensitas 
curah hujan sebesar $18,515 \mathrm{~mm} /$ hari. Pada tanggal 28 November 2017, intensitascurah hujan estimasi di Provinsi Jawa Timur mengalami curah hujan terendah terletak di 3 pos hujan dengan intensitas curah hujan sebesar $0 \mathrm{~mm} /$ hari, sedangkan curah hujan tertinggi te rletak pada Pos Hujan Arjosari dengan intensitas curah hujan sebesar 15,861 $\mathrm{mm} /$ hari.

Pola Intensitas Curah Hujan Estimasi pada 26, 27 dan 28 Desember 2017

Pada tanggal 26 Desember 2017, intensitas curah hujan estimasi di Provinsi Jawa Timur mengalami curah hujan terendah terletak di 5 pos hujan dengan intensitas curah hujan sebesar $0 \mathrm{~mm} /$ hari, sedangkan curah hujan tertinggi terletak pada Pos Hujan Stamet Tuban dengan intensitas curah hujan sebesar 15,332 mm/hari. Pada tanggal 27 Desember 2017, intensitas curah hujan estimasi di Provinsi Jawa Timur mengalami curah hujan terendah terletak di 4 pos hujan dengan intensitas curah hujan sebesar $0 \mathrm{~mm} /$ hari, sedangkan curah hujan tertinggi terletak pada Pos Hujan Setren dengan intensitas curah hujan sebesar 15,144 $\mathrm{mm} /$ hari. Pada tanggal 28 Desember 2017, intensitas curah hujan estimasi di Provinsi Jawa Timur mengalami curah hujan terendahterletak di 4 pos hujan dengan intensitas curah hujan sebesar $0 \mathrm{~mm} /$ hari, sedangkan curah hujan tertinggi terletak pada Pos Hujan Kawah Ijen dengan intensitas curah hujan sebesar $14,685 \mathrm{~mm} /$ hari.

\section{Perbandingan Pola Curah Hujan Estimasi dengan Curah Hujan Aktual}

Berbeda dengan curah hujan estimasi dari citra MODIS yang memiliki nilai rata-rata, yaitu antara 0 hingga 18,515 milimeter tiap hari, sedangkan curah hujan aktual menunjukkan nilai yang melebihi sampai 100 milimeter tiap harinya untuk lokasi titik pos hujan tertentu. Meskipun terlihat perbedaan yang jelas antara curah hujan hasil estimasi melalui citra MODIS dengan curah hujan aktual (pos hujan), namun sebenarnya nilai antara keduanya menunjukkan pola yang sama. Visualisasi terkait perbedaan nilai curah hujan hasil estimasi dengan data aktual dapat diketahui pada Gambar 6. Terlihat bahwa terdapat 6 puncak ekstrim yang menunjukkan nilai curah hujan aktual yang berbeda jauh dengan nilai rata-rata pada gambar tersebut. Secara garis besar, nilai curah hujan estimasi memperlihatkan pola yang sama dengan nilai curah hujan aktual. Dapat didefinisikan bahwa nilai curah hujan estimasi melalui citra MODIS termasuk under-estimate dibandingkan nilai curah hujan aktual kecuali kondisi ekstrem (Gambar 7).

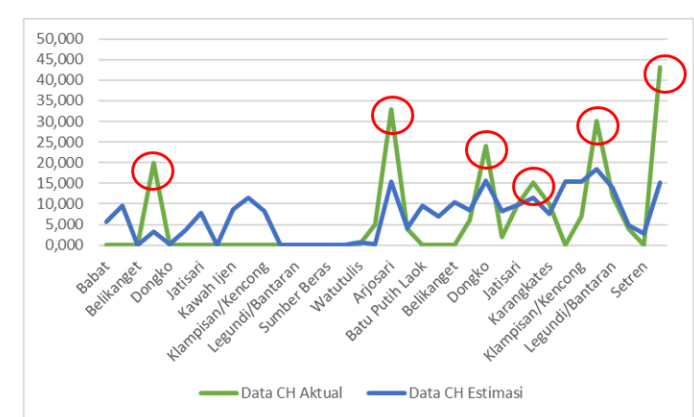

Gambar 6 Grafik Perbandingan Curah Hujan Estimasi dengan Curah Hujan Aktual pada Data Persamaan Regresi Linier Berganda (27-okt-2017 dan 27-nov-2017)

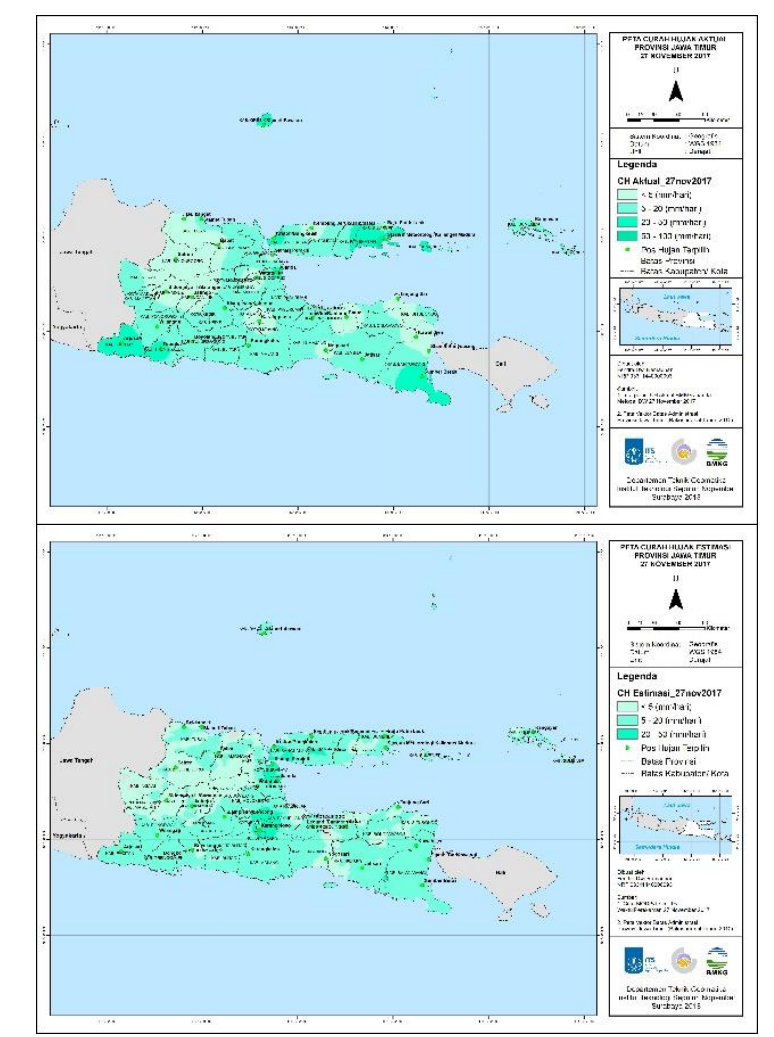

Gambar 7 Curah Hujan Aktual (atas) dan Curah Hujan Estimasi (bawah) pada 27 November 2017 di Provinsi Jawa Timur

Hasil Uji Akurasi dan Uji Korelasi Curah Hujan Estimasi dengan Curah Hujan Aktual

Berdasarkan hasil uji akurasi didapatkan bahwa nilai akurasi yang dihasilkan dari perhitungan RMS Error nilai CH Estimasi terhadap CH Aktual adalah sebesar 8,643 . Yang berarti bahwa nilai kesalahan rata-rata 
yang didapat dari perhitungan $\mathrm{CH}$ Estimasi dengan $\mathrm{CH}$ Aktual yaitu $8,643 \mathrm{~mm} /$ hari. Nilai ini masih masuk dalam toleransi karena nilai RMS Error tersebut dibawah dari nilai std. error of estimate pada hasil perhitungan regresi linier berganda yaitu $8,730 \mathrm{~mm} /$ hari.

Pada Gambar 3.4 dapat diketahui bahwa pada data persamaan regresi linier berganda yaitu 18 titik pos hujan tanggal 27 Oktober 2017 dan 18 titik pos hujan tanggal 27 November 2017 ( 36 titik) didapat suatu model matematis yang terbentuk yaitu $y=0,3158 x+5,0471$. Berdasarkan model tersebut maka dapat diketahui bahwa setiap pertambahan nilai curah hujan hasil estimasi citra MODIS akan diikuti pula penambahan curah hujan pos hujan sebesar $0,3158 \mathrm{~mm} /$ hari dengan nilai koefisien determinansi $\left(R^{2}\right)$ sebesar 0,358 (R $=59,8 \%$ ). Berdasarkan interpretasi koefisien korelasi yang dikemukakan oleh Hasan (2013), dapat dikatakan bahwa nilai korelasi yang didapatkan diatas termasuk dalam korelasi sedang.

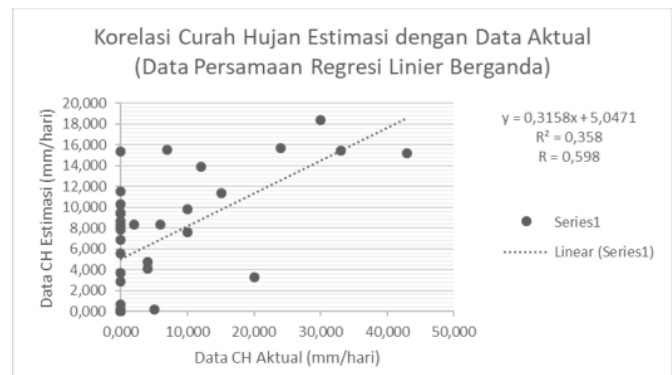

Gambar 8 Korelasi CH Estimasi dengan $\mathrm{CH}$ Aktual

\section{Hasil Analisis Spasial Pola Curah Hujan Estimasi terhadap Ketinggian Wilayah}

Berdasarkan pengolahan analisis spasial, didapatkan informasi bahwa secara keseluruhan total luas wilayah curah hujan estimasi berbedatiap tiap citra dan tiap tanggal perekaman. Dengan total luas wilayah curah hujan estimasi pada bulan Oktober terbanyak pada tanggal 27 Oktober 2017 sebesar $39.888 \mathrm{~km}^{2}$, pada bulan November terbanyak pada tanggal 28 November 2017 sebesar $47.584 \mathrm{~km}^{2}$, sedangkan pada bulan Desember terbanyak pada tanggal 26 Desember 2017 sebesar $45.903 \mathrm{~km}^{2}$. Luas wilayah curah hujan estimasi tersebut juga menandakan luas wilayah di Provinsi Jawa Timur yang tertutup oleh awan yang berpotensi hujan. Curah hujan estimasi pada kelas pertama ( $<5 \mathrm{~mm} /$ hari) banyak tersebar di kelas dataran rendah dibandingkan dataran sedang dan tinggi. Hal ini karena secara visual luas, dataran rendah hampir tersebar di seluruh wilayah Provinsi Jawa Timur, sehingga mengakibatkan nilai luas wilayah curah hujan estimasi di dataran rendah pun bernilai banyak.

\section{KESIMPULAN}

Berdasarkan hasil penelitian yang dilakukan maka dapat didapatkan beberapa kesimpulan, yaitu:

1. Berdasarkan hasil pengolahan data estimasi curah hujan, di dapatkan model matematis $y=$ $44,788-0,194 x_{1}+7,798 x_{2}$, dengan nilai korelasi (R) antara CH Aktual, SPA dan ALB pada persamaan regresi linier berganda sebesar $62,4 \%$ sedangkan nilai koefisien determinansi $\left(R^{2}\right)$ sebesar 0,390 . Nilai intensitas curah hujan yang diperoleh dari citra MODIS berupa estimasi minimal pada bulan Oktober hingga Desember sebesar $0 \mathrm{~mm} /$ hari dan estimasi maksimal pada bulan Oktober sebesar 14,977 $\mathrm{mm} /$ hari, bulan November sebesar 18,515 $\mathrm{mm} /$ hari dan bulan Desember sebesar 15,332 $\mathrm{mm} /$ hari.

2. Berdasarkan hasil perbandingan pola curah hujan estimasi dengancurah hujan aktual pada data regresi linier berganda didapatkan 6 puncak ekstrim yang menunjukkan nilai curah hujan aktual yang berbeda jauh dengan nilai estimasinya. Pola nilai curah hujan estimasi dari citra satelit MODIS termasuk underestimate dibandingkan nilai curah hujan aktual kecuali pada kondisi ekstrem.

3. Berdasarkan hasil perbandingan nilai curah hujan estimasi dengan curah hujan aktual di dapatkan nilai uji akurasi (RMSE) sebesar 8,643 $\mathrm{mm} /$ hari. Nilai ini masih masuk dalam toleransi karena nilai RMSE tersebut dibawah dari nilai std. error of estimate yang didapat pada hasil perhitungan regresi linier berganda yaitu 8,730 $\mathrm{mm} /$ hari. Selanjutnya, didapatkan model matematis $y=0,3158 x+5,0471$, dengan hasil uji korelasi (R) menunjukkan nilai $59,8 \%$ yang menandakan korelasi sedang dengan koefisien determinansi $\left(R^{2}\right)$ sebesar 0,358 .

4. Berdasarkan hasil analisis spasial menunjukkan bahwa ketiga kelas curah hujan $(<5 \mathrm{~mm} / \mathrm{h}$ ari, 5 $-20 \mathrm{~mm} /$ hari dan $20-50 \mathrm{~mm} / \mathrm{hari}$ ) tersebar di ketiga kelas ketinggian wilayah (Dataran Rendah, Dataran Sedang dan Dataran Tinggi) di Provinsi Jawa Timur, dengan luas luas wilayah 
curah hujan estimasi pada bulan Oktober terbanyak pada tanggal 27 Oktober 2017 sebesar $39.888 \mathrm{~km}^{2}$, pada bulan November terbanyak pada tanggal 28 November 2017 sebesar $47.584 \mathrm{~km}^{2}$, sedangkan pada bulan Desember terbanyak pada tanggal 26 Desember 2017 sebesar $45.903 \mathrm{~km}^{2}$.

\section{DAFTAR PUSTAKA}

Behrangi, A., Koulin, H., Bisher, I., \& Soroosh, S. (2010). Daytime Precipitation Estimation Using Bispectral Cloud Classification System. Journal of Applied Meteorology and Climatology, 49, 1015-1031

BMKG. (2017). Press Release Peringatan Dini Cuaca Ekstrem Tanggal 26-28 November 2017 di Wilayah Jawa Timur. Surabaya. <URL:http://juanda.jatim.bmkg.go.id/buletin/cuek s_2628november.pdf>. Dikunjungi pada 15 Desember 2017

BPS Provinsi Jawa Timur. (2017). Provinsi Jawa Timur Dalam Angka 2017.Surabaya.<URL:https://jatim.bps.go.id/public ation/2017/08/11/d618ba11975447a5ffa5f48/pro vinsi-jawa-timur-dalam-angka 2017.html>. Dikunjungi pada 9 Januari 2018

Darajat, R. (2014). Identifikasi Pola Curah Hujan Pada Kondisi El-Nino Melalui Citra MODIS di Provinsi Jawa Timur. Skripsi. Yogyakarta: Fakultas Geografi, Universitas Gadjah Mada

Hasan, M. I. (2013). Pokok-pokok Materi Statistik I (Statistik Deskriptif) (Edisi Kedua). Jakarta: Bumi Aksara

Tjasyono, B. (2009). Meteorologi Indonesia Volume I (Vol. I). Jakarta:BMKG Pusat

\section{LAMPIRAN}

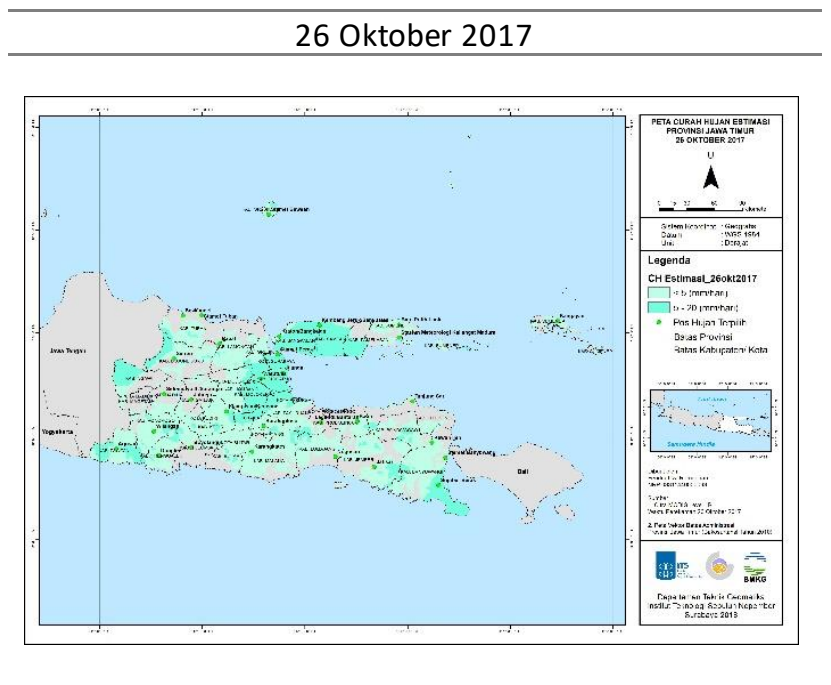

27 Oktober 2017

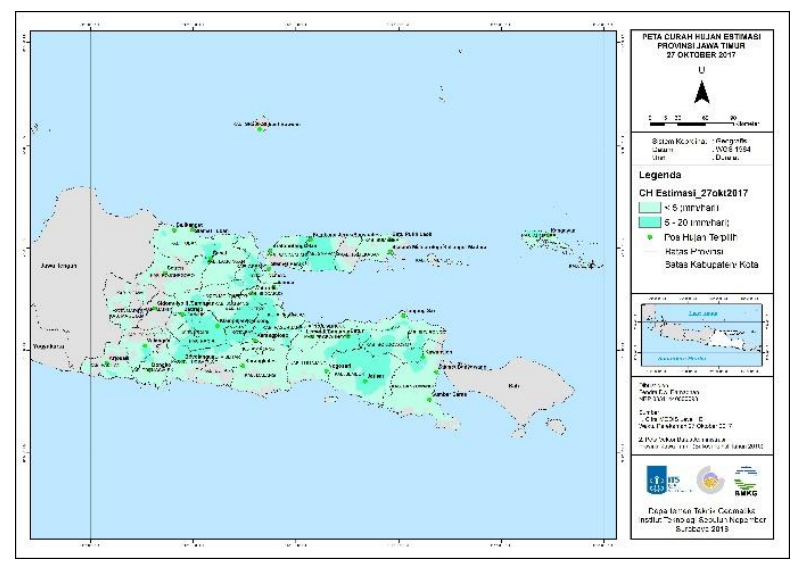

28 Oktober 2017

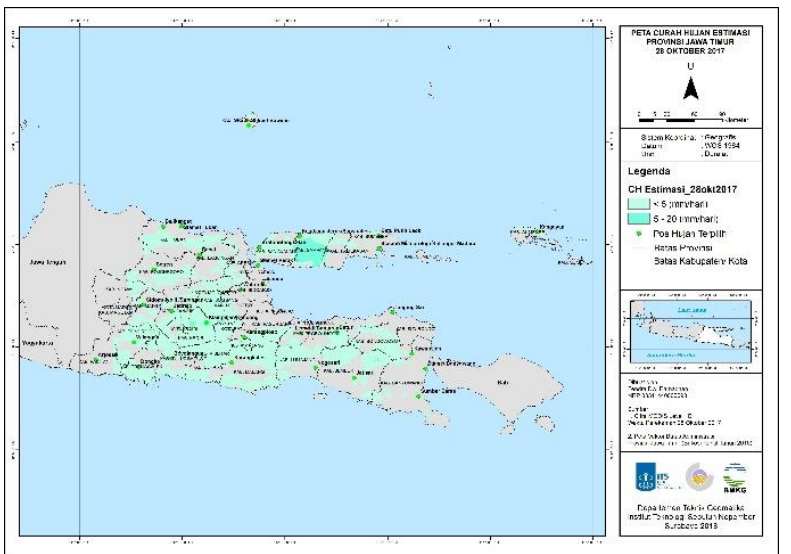




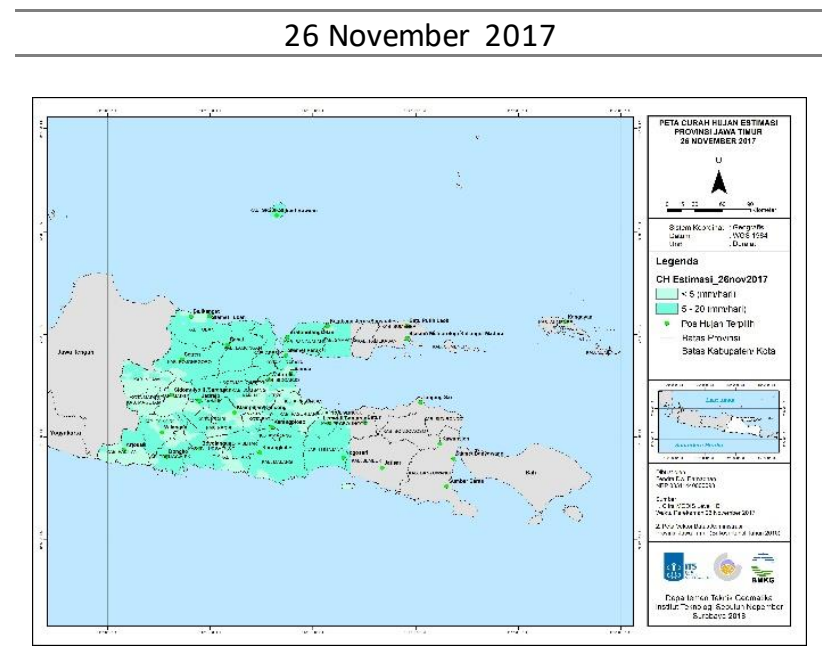

27 November 2017

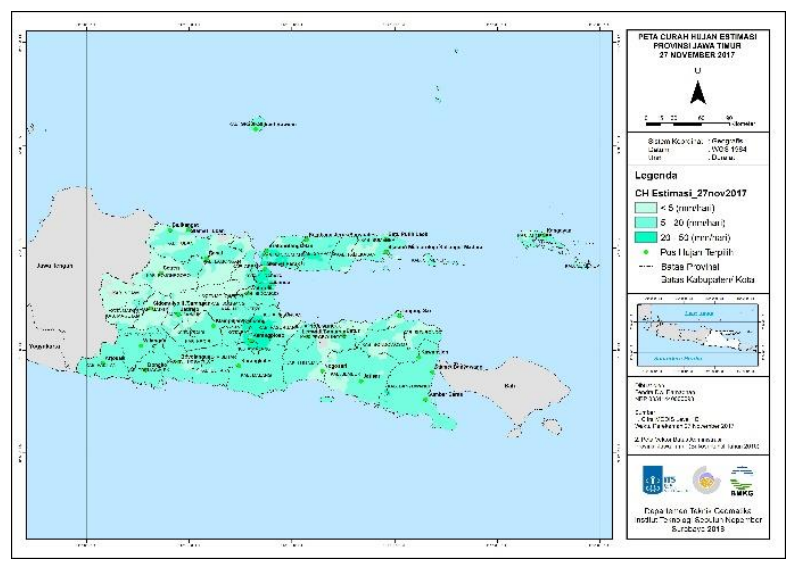

28 November 2017

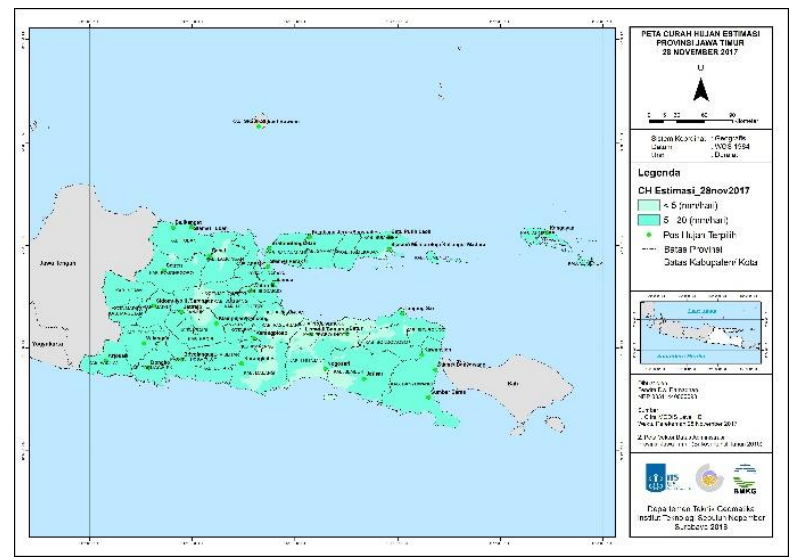

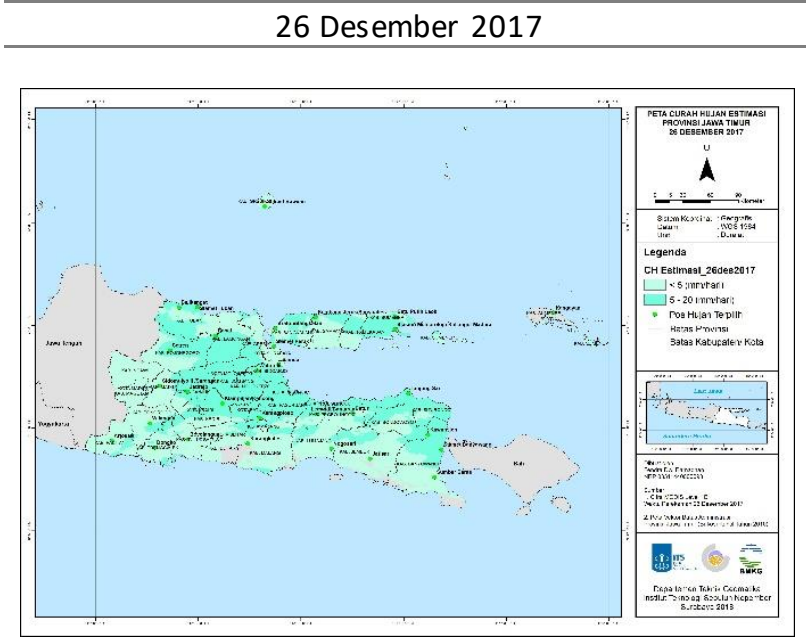

27 Desember 2017

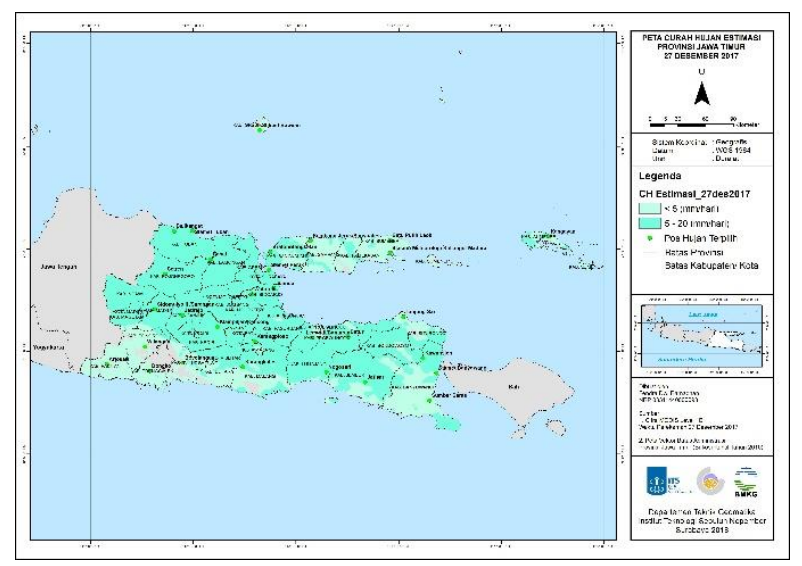

28 Desember 2017

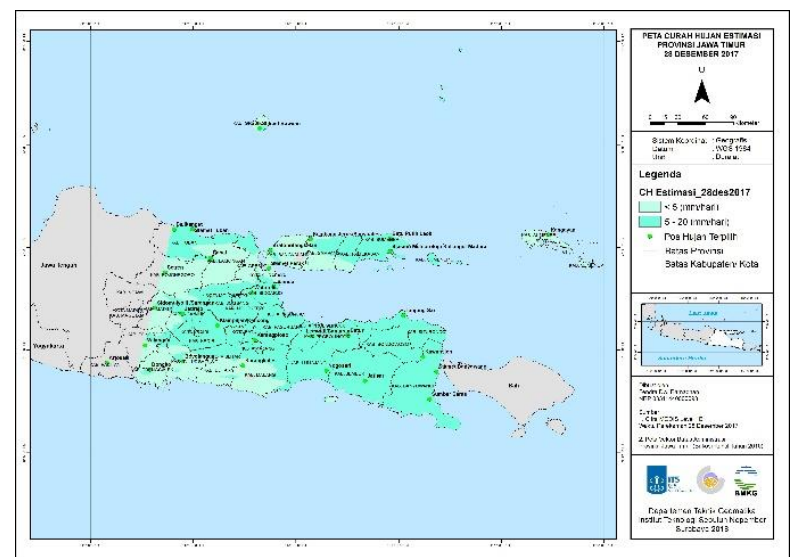


Tabel Sampel Data Curah Hujan Aktual dalam Membangun Persamaan Regresi Linier Berganda

\begin{tabular}{|c|c|c|c|c|c|c|c|}
\hline \multirow[b]{2}{*}{ No. } & \multirow[b]{2}{*}{ Pos Hujan } & \multicolumn{3}{|c|}{ 27-Okt-17 } & \multicolumn{3}{|c|}{ 27-Nov-17 } \\
\hline & & $\begin{array}{c}\text { CH } \\
\text { Aktual } \\
\text { (mm) }\end{array}$ & SPA (K) & $\begin{array}{c}\text { ALB } \\
(\%)\end{array}$ & $\begin{array}{c}\text { CH } \\
\text { Aktual } \\
(\mathrm{mm})\end{array}$ & SPA (K) & $\begin{array}{l}\text { ALB } \\
\text { (\%) }\end{array}$ \\
\hline 1 & Arjosari & - & - & - & 33,000 & 184,457 & 0,692 \\
\hline 2 & Babat & 0,000 & 222,520 & 0,507 & 4,000 & 233,172 & 0,810 \\
\hline 3 & Batu Putih Laok & - & - & - & 0,000 & 211,826 & 0,708 \\
\hline 4 & Batur & 0,000 & 207,933 & 0,647 & 0,000 & 222,187 & 0,759 \\
\hline 5 & Belikanget & 0,000 & 260,143 & 0,212 & 0,000 & 218,085 & 0,386 \\
\hline 6 & Boyolangu & 20,000 & 226,376 & 0,308 & 6,000 & 220,634 & 0,587 \\
\hline 7 & Dongko & 0,000 & 245,730 & 0,393 & 24,000 & 183,850 & 0,680 \\
\hline 8 & Jatirejo & 0,000 & 229,127 & 0,425 & 2,000 & 211,812 & 0,871 \\
\hline 9 & Jatisari & 0,000 & 204,882 & 0,364 & 10,000 & 209,144 & 0,737 \\
\hline 10 & Kangayan & 0,000 & 252,034 & 0,267 & 15,100 & 200,551 & 0,777 \\
\hline 11 & Karangkates & - & - & - & 10,000 & 215,630 & 0,855 \\
\hline 12 & Kawah Ijen & 0,000 & 204,356 & 0,454 & - & - & - \\
\hline 13 & Kembang Jeruk/Banyuates & 0,000 & 192,489 & 0,519 & 0,000 & 190,161 & 0,524 \\
\hline 14 & Klampisan/Kencong & 0,000 & 212,653 & 0,603 & 7,000 & 180,609 & 0,806 \\
\hline 15 & Kraton/Bangkalan & 0,000 & 257,055 & 0,211 & 30,000 & 163,280 & 0,921 \\
\hline 16 & Legundi/Bantaran & 0,000 & 257,931 & 0,403 & 12,000 & 191,615 & 0,689 \\
\hline 17 & Nogosari & - & - & - & 4,000 & 247,203 & 0,282 \\
\hline 18 & Setren & - & - & - & 0,000 & 256,051 & 0,285 \\
\hline 19 & Stasiun Meteorologi Kalianget Madura & 0,000 & 266,950 & 0,200 & - & - & - \\
\hline 20 & Sumber Beras & 0,000 & 250,027 & 0,246 & 43,000 & 176,828 & 0,968 \\
\hline 21 & Tanjung Sari & 0,000 & 241,254 & 0,240 & - & - & - \\
\hline 22 & Watutulis & 0,000 & 244,902 & 0,437 & - & - & - \\
\hline 23 & Wilangan & 5,000 & 239,316 & 0,237 & - & - & - \\
\hline
\end{tabular}

Keterangan:

$(-)=$ Data tidak digunakan 


\begin{tabular}{|c|c|c|c|c|c|c|c|c|c|c|c|c|c|c|c|c|c|c|c|}
\hline \multirow{3}{*}{ No. } & \multirow{3}{*}{ Pos Hujan } & \multicolumn{9}{|c|}{ Data CH Aktual Th. 2017 (mm/hari) } & \multicolumn{9}{|c|}{ Data CH Estimasi Th. 2017 (mm/hari) } \\
\hline & & \multicolumn{3}{|c|}{ Oktober } & \multicolumn{3}{|c|}{ November } & \multicolumn{3}{|c|}{ Desember } & \multicolumn{3}{|c|}{ Oktober } & \multicolumn{3}{|c|}{ November } & \multicolumn{3}{|c|}{ Desember } \\
\hline & & 26 & 27 & 28 & 26 & 27 & 28 & 26 & 27 & 28 & 26 & 27 & 28 & 26 & 27 & 28 & 26 & 27 & 28 \\
\hline 1 & Arjosari & 6,000 & 7,000 & 0,000 & 12,000 & 33,000 & 149,000 & 18,000 & 13,000 & 23,000 & 5,480 & 0,000 & N/A & 3,601 & 15,464 & 15,861 & 1,600 & N/A & N/A \\
\hline 2 & Babat & 0,000 & 0,000 & 0,000 & 5,000 & 4,000 & 43,000 & 0,000 & 0,000 & 12,000 & 0,000 & 5,570 & N/A & 15,604 & 4,116 & 7,668 & 6,256 & 10,222 & 5,051 \\
\hline 3 & Batu Putih Laok & 0,000 & 5,500 & 0,000 & 20,000 & 0,000 & 10,000 & 0,000 & 0,000 & 20,000 & 1,998 & 0,000 & 0,000 & N/A & 9,444 & 9,328 & 5,541 & 1,476 & 6,445 \\
\hline 4 & Batur & 0,000 & 0,000 & 37,000 & 0,000 & 0,000 & 35,000 & 0,000 & 60,000 & 18,000 & 0,000 & 9,493 & 0,000 & N/A & 6,846 & 0,000 & 4,718 & 5,320 & 13,731 \\
\hline 5 & Belikanget & 0,000 & 0,000 & 0,000 & 0,000 & 0,000 & 8,000 & 0,000 & 0,000 & 16,000 & N/A & 0,000 & N/A & 2,900 & 10,333 & 9,323 & 4,130 & 9,537 & 9,019 \\
\hline 7 & Dongko & 0,000 & 0,000 & 0,000 & 14,000 & 24,000 & 58,000 & 59,000 & 17,000 & 14,000 & 0,000 & 0,178 & N/A & 9,112 & 15,677 & 11,113 & 3,359 & 2,493 & 5,139 \\
\hline 8 & Jatirejo & 2,000 & 0,000 & 4,000 & 9,000 & 2,000 & 12,000 & 0,000 & 15,000 & 0,000 & N/A & 3,651 & N/A & 6,510 & 8,309 & 6,793 & 8,015 & 11,031 & 8,046 \\
\hline 9 & Jatisari & 3,000 & 0,000 & 0,000 & 54,000 & 10,000 & 26,000 & $\pi U$ & 7,000 & 11,000 & N/A & 7,876 & N/A & N/A & 9,815 & 8,812 & 0,000 & 6,309 & 12,149 \\
\hline 10 & Juanda & - & - & - & 14,400 & 24,800 & 44,200 & 14,900 & 4,500 & 4,000 & 14,977 & 0,000 & N/A & 3,284 & 16,294 & 8,020 & 2,704 & 13,609 & 10,248 \\
\hline 11 & Kangayan & 0,000 & 0,000 & 0,000 & 13,400 & 15,100 & 0,000 & 0,000 & 21,400 & 8,200 & 0,000 & 0,000 & 0,000 & $\mathrm{~N} / \mathrm{A}$ & 11,392 & 11,395 & N/A & 5,208 & 0,000 \\
\hline 12 & Karangkates & 3,500 & 6,000 & - & 13,000 & 10,000 & 6,400 & 0,200 & 18,000 & 0,400 & 3,975 & 0,000 & 0,000 & 15,128 & 7,592 & 9,503 & 0,000 & 5,459 & 0,000 \\
\hline 13 & Karangploso & 0,000 & 28,800 & 24,000 & 82,100 & 0,800 & - & 1,300 & - & - & 0,000 & 0,000 & 0,000 & 8,449 & 18,515 & 6,119 & 6,470 & 5,691 & 14,574 \\
\hline 15 & Kembang Jeruk/Banyuates & 0,000 & 0,000 & 0,000 & 23,000 & 0,000 & 43,000 & 0,000 & 0,000 & 0,000 & 14,032 & 11,496 & N/A & 5,901 & 15,405 & 11,083 & 6,308 & 2,004 & 2,721 \\
\hline 16 & Klampisan/Kencong & 0,000 & 0,000 & 0,000 & 3,000 & 7,000 & 18,000 & 0,000 & 51,000 & TTU & 2,126 & 8,235 & 4,098 & 4,077 & 15,499 & 10,374 & 12,910 & 8,265 & 12,339 \\
\hline 17 & Kraton/Bangkalan & 0,000 & 0,000 & 10,000 & 17,000 & 30,000 & 20,000 & 3,000 & 2,000 & 0,000 & 0,824 & 0,000 & N/A & 11,145 & 18,438 & 11,407 & 3,638 & 7,207 & 7,175 \\
\hline 18 & Legundi/Bantaran & 0,000 & 0,000 & 0,000 & 0,000 & 12,000 & 3,000 & 0,000 & 48,000 & 0,000 & N/A & 0,000 & N/A & 11,030 & 13,940 & 0,000 & 8,833 & 4,567 & 13,906 \\
\hline 19 & Nogosari & 3,000 & 1,000 & $\pi \mathrm{TU}$ & 17,000 & 4,000 & 2,000 & $\pi \mathrm{U}$ & $\pi \mathrm{T}$ & 1,000 & N/A & 0,000 & N/A & 11,888 & 4,772 & 5,482 & 1,264 & 8,788 & 11,254 \\
\hline 20 & Setren & 0,000 & 0,000 & 0,000 & 0,000 & 0,000 & 0,000 & 0,000 & 0,000 & 0,000 & 0,000 & N/A & 0,000 & 14,661 & 2,837 & 9,335 & 9,105 & 15,144 & 0,000 \\
\hline 21 & Sidomulyo II/Sarangan & 6,000 & 30,000 & 0,000 & 7,000 & 0,000 & 15,000 & 0,000 & 8,000 & 0,000 & N/A & N/A & N/A & 0,000 & 4,474 & 10,906 & 0,238 & 10,241 & 2,872 \\
\hline 22 & Stamet Banyuwangi & 1,400 & - & - & 2,400 & 1,000 & 30,200 & 2,400 & 0,500 & TTU & N/A & 0,000 & N/A & N/A & 14,684 & 14,984 & 11,626 & 4,657 & 11,681 \\
\hline 23 & Stamet Bawean & - & 0,800 & - & 33,200 & 25,100 & 18,200 & $\pi U$ & $\pi U$ & $\pi U$ & 1,113 & N/A & N/A & 8,061 & 10,235 & N/A & 0,000 & 0,000 & 4,806 \\
\hline 24 & Stamet Tuban & $\pi \mathrm{TU}$ & $\pi U$ & - & $\pi U$ & 6,400 & 48,000 & 1,800 & 9,400 & - & N/A & 0,000 & N/A & 5,936 & 9,119 & 9,426 & 15,332 & 11,615 & 8,276 \\
\hline 25 & Stamet Perak II & - & - & 12,200 & 6,200 & - & 16,800 & 3,000 & 7,000 & - & 13,174 & 0,000 & N/A & 12,363 & 17,764 & 11,263 & 1,905 & 11,122 & 0,749 \\
\hline 26 & $\begin{array}{c}\text { Stasiun Meteorologi Kalianget } \\
\text { Madura }\end{array}$ & 0,000 & 0,000 & 0,000 & 3,500 & 70,000 & $\pi U$ & 16,900 & 0,800 & 1,000 & N/A & 0,000 & N/A & $\mathrm{N} / \mathrm{A}$ & N/A & 3,498 & 8,105 & 1,888 & 8,430 \\
\hline 27 & Sumber Beras & 0,000 & 0,000 & 0,000 & 10,000 & 43,000 & 15,000 & 10,000 & 5,000 & 0,000 & 13,138 & 0,000 & N/A & N/A & 15,183 & 15,604 & 0,000 & 1,402 & 9,880 \\
\hline 28 & Tanjung Sari & 0,000 & 0,000 & 0,000 & 0,000 & 0,000 & 16,000 & 0,000 & 25,000 & 43,000 & N/A & 0,000 & N/A & N/A & 10,449 & 5,484 & 15,367 & 2,090 & 9,890 \\
\hline 29 & Watutulis & 0,000 & 0,000 & 0,000 & 112,000 & 0,000 & 30,000 & 0,000 & 0,000 & 0,000 & 13,127 & 0,683 & N/A & 0,968 & 14,936 & 9,191 & 9,387 & 12,842 & 11,061 \\
\hline
\end{tabular}

\section{Keterangan:}

$(-) \quad=$ Tidak hujan $0 \quad=$ Tidak ada hujan TTU = Tidakterukur N/A = NotAvailable 